\title{
A Chequered Renaissance: The Evolution of Maori Society, 1984- 2004
}

\section{Introduction}

In the wake of Labour's euphoric victory in the 1984 General Election, two conferences were swiftly organised by the new Government. The first was an economic summit that took place in September of that year. It sought to proclaim a new period of prosperity for the country - one which would be achieved primarily by means of an extensive liberalisation of the economy.

The following month, the Hui Taumata was convened by the Minister of Maori Affairs, Koro Wetere. It was a summit of Maori leaders that its organisers hoped would herald a period of vigorous and substantial progress for Maori. Not since the height of the Kotahitanga movement in the 1890s had so many hapu and iwi representatives gathered together with the intent to foster Maori development in such a concerted manner. The overriding emphasis of the 1984 Hui Taumata was on the need for significantly increased Maori access to and management of resources. Maori - according to Prime Minister David Lange at the opening of the Hui - were to be the authors of their own subsequent development. ${ }^{1}$

This emphasis on greater Maori self-determination and development, though, was not merely a spontaneous gesture on behalf of the Government. It was as much a reaction to the culmination of forces for change that had been building up for at least a decade. Its immediate paternity included the rise of activist groups such as Nga Tamatoa in the early 1970s, increased Maori politicisation in general, the inception of the Waitangi Tribunal in 1975, a growing Maori population, and the emergence of a strong and articulate Maori intelligentsia. These ingredients formed a potent concoction that any Paul Moon is Professor of History at Te Ara Poutama, AUT University's Faculty of Maori Development, and is a Fellow of the Royal Historical Society at University College, London. 
Government would have had to confront at some point in the near future.

The Hui Taumata undoubtedly became one of the peaks in the landscape of twentieth-century Maori development. In the ensuing two decades, however, the optimism of the Hui was balanced out by an almost equal measure of disappointment as the aspirations of 1984 failed to materialise in many instances.

This chapter explores the twenty years since 1984, with a focus on the experiences of Maori society during that time. Historical periods, however, are arbitrary divisions, as societies are explicable by nothing less than their entire history. ${ }^{2}$ Therefore, what is offered here is primarily an impressionistic survey of these two decades. The material is arranged under three broad timeframes, which correspond with the three Governments that presided over the country during this period. To begin with, though, it is useful to consider the state of Maori society at the commencement of this era.

\section{Maori in 1984: A Snapshot}

The communique issued by the Economic Summit in 1984 painted a fairly gloomy picture of the condition of Maori society at that time. It concluded bluntly that '...the position of Maori is of major concern. The gap between Maori and Pakeha is widening. Racial tension has been growing and many Maori young people have been alienated from the wider community. Maori people and their resources continue to be under-utilised and under-developed'. ${ }^{3}$ While this assessment may have been overly pessimistic, an assembly of statistics from the period reveals that the arithmetic of disparity between Maori and non-Maori was certainly pronounced in many key areas.

By 1984, the Maori population had just nudged over 400,000 , out of a total New Zealand population of 3.25 million. Maori life expectancy, though, was seven years less on average than for non-Maori, Maori infant mortality rates were at 18.4 per 1,000 , compared with 10.7 per 1,000 for the rest of the population, and in the age-group 25 to 64 years, Maori unemployment was at least 70 per cent higher than for nonMaori. 4

Although Maori made up just twelve per cent of the population at this time, half of the people languishing in 
prisons were Maori, Maori admission rates to psychiatric care were substantially higher than for any other ethnic group in the country, 5 and Maori youth suicides accounted for 27 per cent of all youth suicides in the country. ${ }^{6}$

At the same time, te Reo Maori was in serious decline, ${ }^{7}$ there were practically no Maori broadcasting services, ${ }^{8}$ and few specifically Maori health organisations were in operation. ${ }^{9}$ Maori were more likely than non-Maori to leave school without a qualification, and to have lower median incomes. And while 73 per cent of non-Maori owned their own homes in 1984, Maori home ownership was just 45 per cent. ${ }^{10}$

To a considerable extent, this parade of miserable statistics had its antecedents in one-and-a-half centuries of European colonisation, in all its permutations. For decades, instead of offering an outstretched hand to Maori, the machinery of the state seemed to be presenting a clenched fist when it came to providing assistance for Maori development. The figures had become so disparate for Maori and non-Maori by 1984 that they presented an image of two New Zealands bound by geography, but separated by almost every other criterion. While previous Governments had tended to be defensive about this, though, and quick to deflect blame, the ebullient Lange regime promised a Maori cultural and economic renaissance ${ }^{11}$ - one that would be achieved, in large part, by Maori society anchoring itself to the planned-for economic recovery. ${ }^{12}$

\section{4-1989}

Labour's self-assured commitment to its economic reform programme between 1984 and 198713 camouflaged the complicated, temperamental, and sometimes perilous nature of economic transformation. As with practically all outbursts of economic reform, the greater the rate of change, the greater the number of social casualties. ${ }^{14}$ The liberalisation of the country's economy, commencing in the mid-1980s, may have aimed to reduce unemployment, raise living standards, and boost New Zealand's aggregate economic performance, ${ }^{15}$ but in many instances, it was communities with predominantly Maori populations that bore the brunt of these changes.

In several locations around the country, the closure of industries such as the freezing works - often without any warning 16 - resulted in thousands of job losses, 17 and the 
rupturing of entire communities. Many of these singleindustry areas had a high proportion of Maori living in them. ${ }^{18}$ Meanwhile, the almost unbridled access by foreign producers to New Zealand's domestic markets ravaged the local manufacturing sector, again hitting Maori harder than nonMaori.19 For the majority of the Maori workforce - who fell into the category of semi-skilled or unskilled labour 20 - these changes left them and their communities particularly vulnerable to severe social disruption. ${ }^{21}$ Growing inequality in income distribution followed during the next decade, and with it came the scourge of greater poverty 22 and what became known as 'social exclusion'.23 Once more, Maori were disproportionately represented in these categories, ${ }^{24}$ although they were certainly not alone in feeling the effects of the tectonic shifts taking place in the economy.

Maori society as a whole may have been down, but it was certainly not beaten. Against this seemingly bleak backdrop, flickers of a cultural resuscitation could be seen. This return from the brink was underscored by two principal characteristics: it was driven predominantly by 'flax-roots' Maori - unencumbered by the strictures of officialdom; and it was rooted in the desire to nurture te Reo Maori for a new generation of speakers. The emphasis on the language was deliberate - having been identified as the cornerstone of Maori culture, development, and identity. ${ }^{25}$

Much of the groundwork for te Reo's recovery had been done earlier in the decade, during the embryonic stages of the Kohanga Reo movement - a pre-school regime immersed in the Maori language. By the end of the 1980s, the promoters of Kohanga Reo and Kura Kaupapa Maori26 - its school successor - had proven to be the heroes of a bourgeoning Maori cultural and social revival. The growth of the Maori preschool movement was staggering, reaching 416 kohanga throughout the country in 1985,27 and peaking at 765 by 1996.28 Initially, though, the Department of Maori Affairs had only funded a handful of Kohanga, with the first major burst of expansion being driven, and to a large extent funded, by Maori communities themselves. ${ }^{29}$

Despite different ways of defining the number of Maori language speakers in the country, ${ }^{30}$ the statistics reveal that te Reo Maori seems to have been saved - almost at the last moment - from disappearing. ${ }^{31}$ What makes this achievement even more remarkable is that only in the latter part of the decade did the Government finally weigh in with some limited 
support. The passage of the Maori Language Act in 1987, which made te Reo Maori an official language of the country, the establishment of the Maori Language Commission the same year, and the formal recognition of Kura Kaupapa Maori and wananga (Maori tertiary institutions) in the 1989 Education Amendment Act no doubt aided the recovery of the language. ${ }^{32}$ However, without the critical initial impetus from Maori communities, it is difficult to see how these legislative responses would ever have come about.

By the 1980s, the majority of the Maori population had been urbanised for at least a generation. ${ }^{33}$ The consequent intermingling of Maori from different hapu and iwi in an urban setting gave rise to a new form of Maori organisation - one based on the current geographical location of Maori, and not their tribal affiliation. Far from threatening traditional iwi allegiances, however, these urban Maori bodies complemented them - responding to needs that were either specific or more prominent to the urban environment. 34 Organisations such as Te Whanau o Waipareira Trust rapidly seized opportunities in the second half of the 1980s, and beyond, to expand the scope and depth of its activities. For some, these urban Maori authorities were the prototype of a new form of de facto tribal establishment. For others, they were simply an extension of that vein in Maori society that was endlessly adaptable to changes in the environment. 35

Also sensing new demands emerging around them, many tribal-based Maori organisations coalesced into the Federation of Maori Authorities in 1987,36 the purpose of which was to assist primarily with the economic development of its membership. ${ }^{37}$ In hindsight, it may hardly seem like a pioneering venture, but at the time, it was an important advance on anything that had existed beforehand, and like other Maori initiatives in this period, was the product of impulses from within Maori society.

If Maori society had been ill for most of the century, events during the second half of the 1980s breathed new life into the patient. Not only were the Maori language and economy being revitalised by Maori themselves (more so than by paternalist Government intervention), there was also a new virility in Maori cultural expression. The seminal exhibition 'Te Maori', which toured the United States between 1984 and 1986, was of towering importance in its own right, but to some extent it suggested that the successes of Maori culture lay in the past, and bypassed a new age of Maori cultural achievement that 
was beckoning. Maori writers such as Witi Ihimaera, Patricia Grace, and Keri Hulme were coming to greater prominence during the 1980s, as were Maori artists like Robyn Kahukiwa, Ralph Hotere, Kura Te Waru Rewiri, Shona Rapira-Davies, and Cliff Whiting.

The imprint of Maori in the country's cultural terrain was indisputably becoming far more crisp during this time. As a corollary to all these social, organisational, and cultural advances a transformation was about to occur in the way the Government dealt with breaches of the Treaty of Waitangi.

By 1985, the Waitangi Tribunal had been operating for ten years, serving as an ongoing commission of inquiry 38 into Crown breaches of the Treaty since the passage of the Treaty of Waitangi Act 1975. Partly as a concession to its Maori constituents, and partly in an effort to expand the 'arena of catharsis'39 which the Tribunal seemed to offer, in 1985, the Labour Government amended the Act to extend the Tribunal's jurisdiction back to 1840.40 This represented a convenient marriage between Government's preparedness to confront its Treaty obligations, and the immutable urge of many Maori communities to seek redress for grievances that had existed like an abscess, scarring their development often for generations.

Faced with the prospect of finally bringing these grievances out into the open, throughout the country, the organisational apparatus of hapu and iwi began to clank into action. Numerous Maori communities now began to excavate the rich quarry of their own history. By December 1987, 140 claims had been lodged with the Tribunal.41 For most of these claimant groups, the settlement of their grievances was still years away, but there was an immediate benefit in the claims process. As hapu and iwi started to investigate their past particularly bringing into the public domain a previously untapped seam of oral history - a renewed sense of identity was starting to galvanise many Maori individuals and communities. ${ }^{42}$

In addition to the growing number of claims being researched and reported on by the Tribunal, new scholarship on the Treaty was now being fed into the public domain. Claudia Orange's The Treaty of Waitangi, 43 published in 1987, and Sir Hugh Kawharu's edited collection of essays, Waitangi: Maori and Pakeha Perspectives of the Treaty of Waitangi, ${ }^{44}$ issued two years later, both made important contributions to 
the understanding of the Treaty's history, current role, and implications for the country.

\section{The 1990s}

In the six years since 1984, the tangible importance of the Treaty for Maori society had expanded greatly; but what about the rest of the country? The view of non-Maori towards the Treaty was mixed, but in general terms, it seemed to be one of disaffection, periodically accentuated by the odd scowling politician or ill-tempered commentator. Worse still, non-Maori antagonism over the Treaty sometimes shielded a deeper intolerance and prejudice aimed directly at Maori society.

To commemorate the inelegantly-titled sesquicentenary of the signing of the Treaty, and to assuage the underlying trepidation many non-Maori felt over larger and more numerous Treaty claims, 1990 was designated as a year of national celebration. Predictably, perhaps, it turned out to be for the most part an exercise in political ornamentation choreographed to cleanse the nation's conscience as much as inform the public of the underlying issues relating to the history of the Treaty. The past was re-moulded in an image that was palatable to the electorate at large. There was a reenactment of the first signing of the Treaty, a parade of dignitaries gave speeches, a plethora of publications was produced, a commemorative coin and stamp were issued, 45 regional events were organised throughout the country, 46 and the Queen visited in February to attend the commemoration.

While the general public was offered this theatre of the Treaty, the real advances for Maori in Treaty issues were taking place back-stage in the Tribunal. Among the prominent grievances settled in this decade were the Ngai Tahu claim (1991), in which the tribe received a settlement valued at $\$ 170$ million, 47 the fisheries settlement - known as the Sealord Deal (1992) - to which the Government contributed \$150 million, 48 and the Tainui Raupatu claim (1995), valued at $\$ 170$ million. 49 Partly as a result of these settlements, the total value of Maori assets in 2001 had grown to $\$ 8.99$ billion $^{50}$ almost double the value just four years earlier. 51 Furthermore, there were generic reports issued by the Tribunal during this time on matters relating to broadcasting, the Maori electoral option, and radio spectrum management, among others. ${ }^{52}$ Moreover, the inclusion of Treaty principles 
in legislation, which had tentatively begun in the 1980s, was quickening. By the end of 1999, there were references to the Treaty in 29 statutes, 53 of which eleven contained some clauses requiring action in respect of the Treaty. ${ }^{54}$

However, the triumphs of the Tribunal were not necessarily absolute victories for Maori. From 1992, most Treaty settlements fell under the spectre of the Fiscal Envelope. This was a measure by which the Government set aside $\$ 1$ billion for the resolution of all Treaty claims relating to events that took place before September 1992. Moreover, all settlements were to be full and final, with no possibility of claimants reviving their grievances with the Crown in the future.

Although the $\$ 1$ billion cap was later dispensed with, the replacement policy was just as barbed. Claims would be settled ostensibly without a prescribed limit, but at a level consistent with settlements already concluded: virtually the same policy in all but name.

The underlying sense of injustice over limits to settlement amounts was accentuated by the fact that that the payments being made by the Crown were only a fraction of the value of what was being claimed overall. In 2003, Professor Margaret Mutu estimated that the settlements paid out to that time amounted to just 0.06 per cent of what the claims were worth. 55 Too frequently, claimants were wedged into the uncomfortable position of having to accept a tiny portion of what they were demonstrably entitled to, rather than cling to what they felt was just and miss out on a settlement altogether. Also, while the Maori asset base continued to grow, some settlement recipients were encountering challenges in establishing how best to manage their newly (re)-acquired assets. Trying to devise a model that would allocate some of the benefits of these settlements to the claimant communities, while simultaneously attempting to maintain and strengthen the value of these assets proved to be a challenging and in some cases irreconcilable task. ${ }^{56}$

Although it would be wrong to underestimate the importance of the major Treaty settlements of the 1990s, there were signs that Maori society had come to a fork in the road in this decade. One path led to further Treaty claims, negotiations with the Crown, and the faint whiff of settlements many years later. The other path was the route towards greater economic development and independence. Those embarking on this latter course carried the hope of others with 
them. Increasingly, many Maori were becoming disillusioned with the sluggishness of the Tribunal process, and the failure to see any direct benefits flowing from the meagre settlements when they were finally reached. 57

Maori economic development in the 1990s, on the other hand, began to surge ahead in an almost spectacular fashion. 58 By the end of the decade, Maori exports were worth around $\$ 650$ million per annum, there had been a net gain of 8,591 jobs for Maori in the preceding nine years, increases in Maori education and training rates were higher than for nonMaori, and indicators of potential economic innovation ranked Maori as being poised for even more rapid development in the near future. 59

There were, however, a few bumps along the way. Between 1996 and 1997, the reduction between Maori and non-Maori in a range of socio-economic indices - which had been evident since the beginning of the 1990s, had stalled in some cases and begun to widen again in others. ${ }^{60}$ In the twelve months from September 1996, Maori unemployment rose from sixteen to eighteen per cent, representing an estimated increase of 5,500 unemployed Maori.61 The annual average household income for Maori throughout the decade rose at a slower rate than for non-Maori, and in the second half of the decade, there was a slight increase in the number of Maori who were dependent on benefits as the their primary source of income. ${ }^{62}$

Unlike previous decades, though, these short-term setbacks were not sufficient, in themselves, to blight the preconditions for a Maori economic and social take-off. 63 One of the underlying reasons for this was that the profile of Maori society had undergone a fundamental change in the 1990s. The foundations for a recovery had been dug deep, and would not easily be shaken. Education had become one of the main tenets of this new phase of development Between 1994 and 2000, Maori enrolments in tertiary education rose from 27,000 to $40,000,64$ and by the end of the decade, the highest rates of growth in Maori employment were in the highly-skilled and then skilled sectors.65 Maori were increasingly becoming managers, professionals, and technicians, and their earnings were rising accordingly. ${ }^{66}$ All this appeared to be the fulfilment of Apirana Ngata's hope that Maori would one day live '...according to the material standards of the Pakeha and joining with him in the work of the country'. 67

One other development deserves recognition at this juncture, and that is the specific form of the politicisation of 
Maori society that was occurring. This assumed two main forms in the 1990s: the revival of the protest movement, and a greater Maori presence in Parliament.

The introduction of the Fiscal Envelope policy by the National Government, coupled with mounting general concerns over land and Treaty issues, manifested itself in a range of Maori protest activity in the 1990s that had not been seen since the mid-1970s. The Moutoa Gardens in Wanganui were occupied in 1995 by a branch of the local iwi claiming ownership rights, ${ }^{68}$ hui were organised around the country to give vent to anger over the Fiscal Envelope policy, the Takahue School in Northland was occupied by Maori protesters, as was the disused Tamaki Girls College in Auckland, and there was a series of attacks on supposed symbols of British colonialism, including various Victorian-era statues and the lone pine on Auckland's One Tree Hill.

Changes were also occurring for Maori in Parliament. From 1868, when the first four Maori were elected to Parliament - representing the Maori seats that were established by legislation the previous year69 - the Maori presence in the House of Representatives stagnated, and eventually became less significant as the number of general seats rose. In 1996, following the introduction of the MMP (Mixed Member Proportional) system of voting, ${ }^{70}$ there was an increase to five Maori seats in the House, followed by a further rise to seven in 2002. The growth in the number of Maori MPs - both in Maori and general seats ${ }^{71}$ - led to new political arrangements flowering. In 1991, Mana Motuhake, which had battled since 1980 for the promotion of greater Maori autonomy, ${ }^{72}$ merged with the Alliance Party, and its first MP, Sandra Lee, was elected to Parliament in 1993. After the 2002 General election, there were a total of twenty Maori serving as MPs. ${ }^{73}$

Bigger shake-ups were ahead though. Following the 1996 General Election, the National and New Zealand First parties formed a coalition Government. In a surprising result, New Zealand First had succeeded in seizing all the five Maori seats from Labour. It seemed to have become a de facto Maori party, making it an unfamiliar and uncomfortable bed-fellow for the centre-right National party. However, when this coalition collapsed in August 1998, New Zealand First unravelled. Out of the debris, two essentially new parties were strung together. One was a rump New Zealand First, and the other was an attempt ostensibly at a Maori and Polynesian 
party - Mauri Pacific - which was made up of the Maori exNew Zealand First MPs in Parliament.

Following a series of high-profile disclosures about the activities of some of the MPs in Mauri Pacific, the party cobbled together a minuscule 4,008 list votes and 9,321 candidate votes in the 1999 General Election, and duly selfdestructed soon afterwards. ${ }^{74}$

At the heart of this shifting and sorting process in Maori Parliamentary politics was a principle that far too few Maori politicians were inclined to accept: that Maori were just as pluralistic as any other people, and that the presumption that there could possibly be a 'one-size-fits-all' Maori political party appeared to be exactly that - presumptuous.

\section{$2000-2004$}

From one perspective, a Maori party was an increasingly unlikely proposition in the new millennium - simply a relic of many earlier failed efforts to achieve Maori political unity. Yet, the allure of such a body acquired an added lustre whenever Government policies seemed to be attacking the interests of Maori. It appeared that Maori society evinced its greatest unity when it felt it was being besieged. Exactly this sort of collision between hostile Government policy and Maori interests took place in 2004, when the Government rushed through legislation that vested the country's foreshore and seabed in Crown ownership - contrary to Article the Second of the Treaty and Te Turi Whenua Maori Act 1993,75 and extinguishing a decision by the Court of Appeal that the Maori Land Court had the jurisdiction to investigate customary ownership of the foreshore and seabed. 76

There was a surge of Maori solidarity in opposition to the proposed legislation, culminating in a 20,000-strong hikoi that reached Parliament Buildings on 5 May 2004,77 and the formation of a political party geared to advocate for Maori interests in Parliament. The creation of the Maori Party was, in one sense, just the most recent manifestation of the spirit of kotahitanga that had a pedigree extending back as far as 1835. In this sense, the existence of the Party was more about a way of looking at the world that is peculiar to Maori than it was about the tangle of temporary political interests.

To some, Maori politics had advanced by the formation of a specifically Maori national political organisation, but there was 
little in the Maori Party that had not been seen in previous Maori national political movements. However, this is not to dismiss its contribution. The frail state of race relations in the country had been exposed in the aftermath of a provocative speech given by National Leader, Don Brash, at the beginning of 2004. Brash's talk on the Treaty, and allegedly favourable treatment received by Maori ${ }^{78}$ prompted the Race Relations Conciliator, Gregory Fortuin, to say that he was '...hearing alarm bells'.79 The Maori Party may not have been a salve to Brash's scorching rhetoric, but at least it provided a counterpoint to political views that were unsympathetic to Maori.

\section{Maori in 2004: A Snapshot}

Twenty years on, had the profile of Maori society really changed in any substantial way, and was the outlook in 2004 any less pessimistic than it had been in 1984? Possibly the most obvious change in this time had been in the population figures. The number of people in the country identifying themselves as Maori had risen over twenty years by around 210,000, giving a total Maori population in 2004 of approximately $610,000.80$ The gap in life-expectancy between Maori and non-Maori was roughly the same throughout this period. However, for both groups, life expectancy had grown by about four years in the two decades from $1984 .{ }^{81}$

The number of Maori leaving the education system with no qualifications had plummeted drastically during this time. Whereas in 1986, the figure had been close to 70 per cent, by 2003 , it was below 40 per cent. Similarly, in the category of school and post-school qualification attainment, 24 per cent of Maori achieved a qualification in 2003, compared to just nine per cent in 1986.82 But the most impressive educational achievements for Maori lay in the tertiary sector. 85,000 Maori were enrolled in the public tertiary sector in 2003, compared with just 27,000 a decade earlier. ${ }^{83}$ This increase was complemented by the rise in the number of Maori industry trainees, from 10,600 in December 2000 to 16,400 by June 2004.84

The gulf between rates of unemployment between Maori and non-Maori had widened in this period. In March 2004, Maori unemployment was just over nine per cent, while the non-Maori rate was almost a third of that figure. ${ }^{85}$ However, 
the type of employment Maori were acquiring mitigated these figures to some extent. Between 1992 and 2003, there was an almost 120 per cent growth in the number of Maori in highlyskilled employment ${ }^{86}$

The one achievement that really illuminated the extent of the Maori renaissance since 1984 was the revival of te Reo Maori. Largely through the energetic and resourceful efforts of both Te Taura Whiri i te Reo Maori - the Maori Language Commission - and the persistent and often enterprising endeavours of several Maori communities throughout the country, the almost terminal decline of the Maori language by 1984 had not only been halted, but reversed. Moreover, gains in the language were spreading into mainstream New Zealand culture and society 87 in a fashion that only the most optimistic would have conceived of two decades earlier.

Another conspicuous area of progress was Maori Broadcasting, which by 2004 included several local Maori radio stations, and a national Maori television station 88 that in turn was helping to sustain a flourishing Maori media production sector. ${ }^{89}$ Although in its early stages, the link between the existence of Maori television and the maintenance of te Reo Maori was made an explicit outcome for the station, 90 and augured well for the language's survival into the foreseeable future.

In the health field, Maori had a presence on all regional health boards, ${ }^{91}$ traditional Maori healing was gaining currency among Maori, non-Maori, and even the health profession, ${ }^{92}$ and by 2004, there were 240 Maori health providers in the country, all of which operated under a specifically Maori kaupapa to provide more relevant health and disability services predominantly to a Maori clientele. 93

On the negative side of the ledger, while Maori made up fifteen per cent of the country's total population in 200494 (up from twelve per cent in 1984), Maori youth suicide was at around 26 per cent of all youth suicide - virtually unchanged in twenty years. ${ }^{95}$ Similarly, Maori prison incarceration rates remained almost the same as they had been in 1984,96 Maori home ownership had increased, but still lagged behind those rates for non-Maori, 97 and Maori incomes continued to be lower than for most other ethnic groups in the country. 98

While overall, the inequalities between Maori and nonMaori were less glaringly obvious in 2004 than they had been at the time of the first Hui Taumata, this in no way excused the fact that they still existed. Buried beneath twenty years of 
Government reports, meetings, speeches, policies, and research was little for any administration during this period to be proud of. The ethnic fault line separating Maori from nonMaori was still jutting out in so many areas. And yet, advances in Maori society had been made since 1984.

How did such a seemingly unresponsive official climate allow for so many instances of progress in Maori society to transpire? The answer is that where real improvements were occurring, Maori communities were often found to be at their core - coming up with plans, engineering policies, stitching together resources, and pursuing ideas with the sort of commitment and creativity that high-handed Government departments could follow (sometimes with a dose of goodwill), but never really match. Perhaps this was the real key to the successful evolution of Maori society in the two decades after 1984: a sort of self-fertilising development, achieved as much in spite of Government assistance as because of it. It was Maori communities and a reinvigorated Maori leadership that defined the kaupapa for this development and that led the charge from the front. This, then, was where the epicentre of the Maori renaissance was located.

\section{Conclusion}

The buoyant expectations of the 1984 Hui Taumata did not quite come to fruition in the way its participants may have hoped for. Indeed, in retrospect, it would have been naïve to expect anything else. The burden of over a century of disadvantage and discrimination proved too difficult to dislodge in so short a time. Moreover, beneath the grand aspirations for improvement was a fatal lack of detail on the mechanics of how these ideas would be brought about. However, the Hui did mobilise and give voice to a will in Maori society to overcome the myriad hurdles strewn in front of it. This, in turn, set the general tone for the paradigm of Maori development during the next twenty years.

By 2004, examples of Maori achievement had become as varied as they were numerous. In education, industry, government, the arts, and a host of other fields, the presence of successful Maori was first anticipated, then expected, and then finally, accepted as the norm. As Maori explored new tributaries of development, the profile and perception of Maori society began to evolve. With a higher proportion of Maori 
university graduates than ever before, greater recognition of Treaty issues, both in legislation and in the public arena, more te Reo speakers than at any other time in living memory, and a stronger Maori political voice in the country, overall, Maori society was in a healthier state in 2004 than it had been for generations, and was primed for even greater achievements in the future.

\section{Notes}

D. R. Lange, in Maori Economic Development Summit Conference: Conference Proceedings, Wellington, 1984, A1 - B1.

2 R. W. Emerson, 'History', in J. P. (ed.), Works of Ralph Waldo Emerson, Edinburgh, W. P. Nimmo, Hay \& Mitchell, 1906, p. 1.

3 Economic Summit Conference Communiqué, Wellington, Economic Summit Secretariat, 1984, paragraph 18.

$4 \quad$ New Zealand Official Yearbook 1986 - 1987, Wellington, Department of Statistics, 1986, pp. 152-3, 187, 245, 327, \& 356; New Zealand Official Yearbook 1987 - 1988, Wellington, Department of Statistics, 1987, pp. 147 \& 229.

5 New Zealand Official Yearbook 1986 - 1987, p. 187; New Zealand Official Yearbook $1987-1988$, p. 302.

6 New Zealand Health Information Service, 'Health Statistics on Youth Suicide', Wellington, Ministry of Health, 2002.

7 Waitangi Tribunal, Report of the Waitangi Tribunal on the Te Reo Maori Claim, Wai-11, Wellington, Department of Justice, April 1986, 3.2.11, 3.3.2, 3.3.4.

8 Royal Commission of Inquiry. Broadcasting and Related Telecommunications in New Zealand, Wellington: Government Printing Office, 1986, pp. $312 \mathrm{ff}$

9 C. A. Kiro, 'Kimihia mo te Hauora Maori: Maori Health Policy and Practice' PhD Thesis, Massey University, 2000, chapter five.

$10 \quad$ New Zealand Official Yearbook 1986 - 1987, pp. 153, 245, \& 356.

11 D. R. Lange, in Maori Economic Development Summit Conference: Conference Proceedings, A1 - B1.

12 R. Kerr, '1984 - 2004: Twenty Years On', Speech to Wanganui Chamber of Commerce, 25 February 2004, p. 2.

13 Ibid., pp. 1-3.

14 See N. J. Smelser, 'The Modernisation of Social Relations', in W. Myron, (ed.), Modernisation: The Dynamics of Growth, Washington, Voice of America, 1966, pp. 119-130.

15 R. Douglas, 'Aim of 1980s Privatisation Misunderstood', in New Zealand Herald, 22 August 2002.

16 P. Firkin, R. Cremer, A. de Bruin, A. Dupuis, \& P. Spoonley, 'A Great Place to Work? A Comparative Analysis of Three Regional Labour Markets', Working Paper No. 3, Labour Market Dynamics Research Programme, Auckland, Massey University, 2001, p. 8.

17 P. Hyman, 'The New Zealand Experiment: Not the Major Success that Politicians Claim', Wellington, Victoria University of Wellington, 1996, p. 6. such as Whakatu and Waitara.

19 Monitoring and Evaluation Branch, Te Puni Kokiri, Fact Sheet 3: Maori Unemployment, Wellington, Te Puni Kokiri, June, 1999, p. 1. 
$20 \quad$ New Zealand Official Yearbook 1986-1987, pp. 328-9.

21 International Research Institute for Maori and Indigenous Education, Iwi and Maori Provider Success: A Research Report of Interviews with Successful Iwi and Maori Providers and Government Agencies, Wellington, Te Puni Kokiri, 2002, p. 2; A. E. Joseph, J. M. Lidgard, \& R. Bedford, 'Dealing With Ambiguity: On the Interdependence of Change in Agriculture in Rural Communities', in New Zealand Geographer, Vol. 57, no. 1, Christchurch, New Zealand Geographical Society, 2001, p. 21.

22 P. Dalziel, 'New Zealand's Economic Reforms: An Assessment', in Review of Political Economy, Vol. 14, No. 1, Oxford, Routledge, 2002, p. 42.

23 R. Stephens, P. Frater, \& C. Waldegrave, 'Below the Line: An Analysis of Income Poverty in New Zealand, 1984-1998', Graduate School of Business and Government Management Working Paper 2/00, Wellington, Victoria University of Wellington, 2000, p. 31

24 S. Chapple, 'Maori Socio-economic Disparity', Paper for the Ministry of Social Policy, Wellington, Department of Labour, September 2000, pp. $12 \mathrm{ff}$.

25 He Reo e Korerotia Ana - He Reo Ka Ora: A Shared Vision for the Future of Te Reo Maori, Wellington, Te Puni Kokiri, March 2003, p. 1.

26 Kura Kaupapa Maori, No. 10, Winter, Wellington, Education Review Office, 1995, p. 1

27 Waitangi Tribunal, Report of the Waitangi Tribunal on the Te Reo Maori Claim, 3.3.10

28 E. Rata 'Maori Language Revival in New Zealand Education', draft, Auckland, Auckland College of Education, January 2004, p. 12, used with the kind permission of Dr. Elizabeth Rata.

29 A. Meade \& V. N. Podmore, 'Early Childhood Education Policy Coordination under the Auspices of the Department/Ministry of Education: A Case Study of New Zealand', Early Childhood \& Family Policy Series No. 1, Paris, UNESCO, March 2002, p. 12.

30 Maori Language Team, Te Puni Kokiri, Te Reo Maori i te Hapori: Maor Language in the Community, Wellington, Te Puni Kokiri, July 2004, p. 28.

31 Waitangi Tribunal, Report of the Waitangi Tribunal on the Te Reo Maori Claim, 3.3.4 \& 3.3.6.

32 Education Review Office, Te Tari Arotake Matauranga, Kura Kaupapa Maori, No. 10, Wellington, Education Review Office, Winter, 1995.

33 I. Pool, Te Iwi Maori: New Zealand Population, Past, Present and Projected, Auckland, Auckland University Press, 1991.

34 S. Chapple, pp. 12, 16, 18, 21, \& 22

35 P. Keiha \& P. Moon, 'Urban Maori Authorities', Draft, Auckland, Auckland University of Technology, 2004.

36 Established under the Incorporated Societies Act 1908

37 Rules of the Federation of Maori Authorities (Incorporated). Amendment for registration under the Incorporated Societies Act 1908.

38 Treaty of Waitangi Act 1975, second schedule, clause 8; also see Commissions of Inquiry Act 1908.

39 E. J. Kelsey, Rogernomics and the Treaty of Waitangi: The Contradiction Between the Economic and Treaty Policies of the Fourth Labour Government, 1984-1990, and the Role of Law in Mediating that Contradiction in the Interests of the Colonial Capitalist State', PhD Thesis, University of Auckland, 1991, p. 624.

40 Treaty of Waitangi Amendment Act 1985, s. 3.

41 A. Ward, An Unsettled History: Treaty Claims in New Zealand Today, Wellington, Bridget Williams Books, 1999, p. 31. 
42 A. Sharp, Justice and the Maori: Maori Claims in New Zealand political Argument in the 1980s, Auckland, Oxford University Press, 1990, pp. 8798, \& 161 .

43 C. Orange, The Treaty of Waitangi, Wellington, Bridget Williams Books, 1987.

44 I. H. Kawharu (ed.), Waitangi: Maori and Pakeha Perspectives of the Treaty of Waitangi, Auckland, Oxford University Press, 1989.

45 The denomination of the coin was $\$ 150$, and it had a mintage of 3,200 ; the stamps came in 40c and 80c denominations.

46 J. Metge, 'Ropeworks: He Taura Whiri', Speech, February 2004.

47 Te Runanga o Ngai Tahu, 'The Deed of Settlement: Key Points', Christchurch, Te Runanga o Ngai Tahu, 2003.

48 See P. Moon, The Sealord Deal, Palmerston North, Campus Press, 1999 chap. 5 .

49 The Treasury, New Zealand Economic and Financial Overview 2000 Wellington, The Treasury, March 2000. Also see Waikato Raupatu Claims Settlement Act 1995.

50 F. Scrimgeour and C. Iremonger, Maori Sustainable Economic Development in New Zealand: Indigenous Practices for the Quadruple Bottom Line, Hamilton, University of Waikato, 2004, p. 9.

51 Economic Opportunities Team, Te Puni Kokiri, The Maori Commercial Asset Base: Te Hua Ohanga Maori - a motu, Wellington, Te Puni Kokiri, December 2003, p. 3.

52 Waitangi Tribunal, Report of the Waitangi Tribunal on Claims Concerning the Allocation of Radio Frequencies, Wai 150, Wellington, Department of Justice, 1990; Broadcasting Report, Wai 176, Wellington, Department of Justice, 1991; Maori Electoral Option Report, Wai 413, Wellington, Department of Justice, 1994; Radio Spectrum Management and Development Interim Report, Wai 776, Wellington, Department of Justice, 1999.

53 Conservation Act 1987 (section 4); Crown Pastoral Land Act 1998 (section 25, section 84); Crown Research Institutes Act 1992 (section 10); Crown Minerals Act 1991 (section 4); Education Act 1989 (section 181(b) (added 1990)); Foreshore and Seabed Endowment Revesting Act 1991 (section 3); Harbour Boards Dry Land Endowment Revesting Act 1991 (section 3); Hazardous Substances and New Organisms Act 1996 (section 8); Resource Management Act 1991 (section 8); State-Owned Enterprises Act 1986 (section 9); Treaty of Waitangi Act 1975 (section 6 (1)); Crown Forests Assets Act 1989; Education Lands Act 1949; Environment Act 1986 (long title); Fisheries Act 1996; Legal Services Act 1991; Local Legislation Act 1989; Mäori Fisheries Act 1989; Mäori Language Act 1987; Ngai Tahu Claims Settlement Act 1998; Ngai Tahu (Pounamu Vesting) Act 1997; Ngai Tahu (Tutaepatu Lagoon Vesting) Act 1998; Ngati Turangitukua Claims Settlement Act 1999; Orakei Act 1991; Te Ture Whenua Maori (Maori Land) Act 1993; Treaty of Waitangi (Fisheries Claims) Settlement Act 1992 ; Treaty of Waitangi (State Enterprises) Act 1988; Waikato Raupatu Claims Settlement Act 1995; Waitutu Block Settlement Act 1997; see Te Puni Kokiri, He Tirohanga o Kawa ki te Tiriti o Waitangi: A Guide to the Principles of the Treaty of Waitangi as expressed by the Courts and the Waitangi Tribunal, Wellington, Te Puni Kokiri, 2001, p. 111.

54 Te Puni Kokiri, He Tirohanga o Kawa ki te Tiriti o Waitangi: A Guide to the Principles of the Treaty of Waitangi as expressed by the Courts and the Waitangi Tribunal, p. 111. 
55 'Maori being short-changed, claims expert', in New Zealand Herald, 26 July 2003. Figures used with the kind permission of Professor Margaret Mutu.

56 Twelve years of dispute and litigation over the allocation of the assets of the Maori Fisheries Settlement of 1992 demonstrated how tortuous the allocation question could be.

57 National Radio 8am Bulletin, Tuesday, 11 July 2000, 8:12 am; 'Tribe fails in legal duty: ex-CEO', in New Zealand Herald, 11 June 2002.

58 New Zealand Institute of Economic Research, Maori Economic Development: Te Ohanga Whanaketanga Maori, Wellington, New Zealand Institute of Economic Research, 2003, p. 14.

59 Ibid., pp. 15, 23, 27, \& 67.

60 Te Puni Kokiri, 'Trends in Maori Employment, Income and Expenditure', in Whakapakari: Hunga Mahi, No. 2, Wellington, Te Puni Kokiri, 1998, p. 4.

61 Op. cit.

62 ibid., pp. 4-5.

63 For an analysis of the preconditions for a take-off, see W. W. Rostow, 'The Take-Of into Self-Sustained Growth', in Economic Journal, Vol. 66, New York, March, 1956, pp. 25-48; N. J. Smelser, pp. 119-130.

64 Department of Labour, Maori Pathways - Te Ara Maori', in Work Insight, fifth edn., Wellington, Department of Labour, November 2004, p. 16.

65 Statistics New Zealand, Household Labour Force Survey, in ibid., p. 13.

66 Op. cit

67 A. T. Ngata, introduction to Nga Moteatea, Part 1, Wellington, A. H. and A. W. Reed, 1959, cited in R. J. Walker, He Tipua: The Life and Times of Sir Apirana Ngata, Auckland, Penguin Books, 2001, p. 223.

68 P. Moon, 'The History of Moutoa Gardens and Claims of Ownership', in The Journal of the Polynesian Society, Vol. 105, No. 3, Auckland, The Polynesian Society, 1996, pp 347-365.

69 Maori Representation Act 1867

70 MMP introduced following a national referendum in 1993.

71 Maori elected to general seats in the 1990s included Winston Peters, Ian Peters, Jill Pettis and Georgina Beyer.

72 L. Cox, Kotahitanga: The Search for Maori Political Unity, Auckland, Oxford University Press, 1993, pp. 135-6.

73 These were: Donna Awatere-Huata, Georgina Beyer, Bill Gudgeon, Dave Hereora, Parekura Horomia, Nanaia Mahuta, Moana Mackey, Ron Mark, Mahara Okeroa, Pita Paraone, Edwin Perry, Jim Peters, Winston Peters, Jill Pettis, Mita Ririnui, Dover Samuels, John Tamihere, Georgina Te Heu Heu, Metiria Turei, and Tariana Turia.

74 Ministry of Justice, 'Statistics', in The General Election 1999, Wellington, Ministry of Justice, May 2000.

75 The Foreshore and Seabed - Maori Customary Rights and Some Legal Issues, Wellington, Parliamentary Library, 12 December 2003, p. 1.

76 Waitangi Tribunal, Report on the Crown's Foreshore and Seabed Policy, Wai1071, Wellington, Legislation Direct, 2004.

77 New Zealand Herald, 5 May 2004.

78 D. Brash, 'Nationhood: An address by Don Brash Leader of the National Party to the Orewa Rotary Club on 27 January 2004', Press release, Tuesday, 27 January 2004, 8:29 pm.

79 G. Fortuin, 'Brash - Nation-Building or Road to Conflict', Press release, Thursday, 5 February 2004, 8:54 am.

80 Statistics New Zealand, 'National Maori Population Projections, 2001 (base) -2021', table, Wellington, Statistics New Zealand, May 2003. 
81 These are approximate figures, based on extrapolations of the statistics provided. Ministry of Social Development, 'Life expectancy at birth, by ethnic group and sex 1950-52 to 2000-02', figure H2.2, in The Social Report: Te Purongo Oranga Tangata 2004, Wellington, Ministry of Social Development, 2004. These are approximate figures, based on extrapolations of the statistics provided.

Department of Labour, 'Maori Pathways - Te Ara Maori', p. 14

Ibid., p. 16.

Ibid., p. 19.

85 Department of Labour, Employment and Unemployment: September 2004 Quarter, Wellington, Department of Labour, 12 November 2004, p. 5.

86 Department of Labour, 'Maori Pathways - Te Ara Maori', p. 13.

87 For the areas of activity of the, Te Taura Whiri i te Reo Maori, see The Maori Language Commission, The Annual Report of the Maori Language Commission for the Year Ended 30 June 2003, Wellington, Maori Language Commission, 2003.

88 Founded under the Maori Televisions Service Act (Te Aratuku Whakaata Irirangi Maori) 2003.

89 Maori Television, Maori Television: Statement of Intent, 2004/2005, Auckland, Maori Television, 2004

90 Ibid., pp. $13 \mathrm{ff}$.

91 Ministry of Health, Whakatataka: Maori Health Action Plan 2002 - 2005 , Wellington, Ministry of Health, November 2002, p. 6.

92 See P. Moon, Tohunga: Hohepa Kereopa, Auckland, David Ling Publishing, 2003, for the role of traditional Maori healing in contemporary New Zealand society.

93 Ministry of Health, He Korowai Oranga: Maori Health Strategy, Wellington, Ministry of Health, November 2002; S. Crengle, R. Lay-Yee, P. Davis, et al., Maori Providers: Primary Health Care Delivered by Doctors and Nurses. The National Primary Medical Care Survey (NatMedCa): 2001/02, Report 3, Wellington, Ministry of Health, 2004, pp. 2-3; J. De Raad, PHOs and Maori Health Implications of PHO Policy for Maori Health Policy Objectives Report to Maori Health Directorate, Ministry of Health, Wellington, New Zealand Institute of Economic Research, 2003.

94 Statistics New Zealand, 'Estimated Resident Population of New Zealand', Wellington, Statistics New Zealand, November 2004

95 These are approximate figures, based on extrapolations of the statistics provided. Ministry of Health, Youth Suicide Facts: Provisional 2000 Statistics (15 - 24 Year Olds), Wellington, Ministry of Health, October 2002, pp. 5-7.

96 Department of Corrections, 'Forecasts by Ethnicity', in Offender Forecasts to 2013, Wellington, Department of Corrections, 2001.

97 Statistics New Zealand, 'National Trend', in Maori Ethnicity in Households Tenure of Household, Wellington, Statistics New Zealand, 2001.

98 Te Puni Kokiri, 'Trends in Maori Employment, Income and Expenditure', p. 1. 